\title{
WAARDENBURG SYNDROME INHERITED DEAFNESS WITH PIGMENTARY INVOLVEMENT
}

\author{
M.F. Macrae, B.Soc.Sc., R.G.N., R.M., \\ Genetic Sister, Department of Human Genetics, \\ Medical School, University of Cape Town.
}

\section{OPSOMMING}

Die kenmerke van die Waardenburgsindroom is die eerste keer in 1905 deur Hammerschlag bespreek. Waardenburg' sou egter eers in 1951 die data byeen moes bring en dit as 'n nuwe sindroom aanbied. Daar is 6 basiese kenmerke van die sindroom wat die meeste werkers aanvaar, maar die werklike verhoudings wat elkeen verteenwoordig, verskil van studie tot studie. Afgesien hiervan is daar verslae van ander bevindings wat met die siekteaandoening skakel of parallel daarmee loop.

\section{INTRODUCTION}

$\mathbf{T}$ HE Waardenburg syndrome was first clearly defined in 1951. The major clinical importance lies in the fact that about $20 \%$ of affected individuals are deaf. Furthermore, because the condition is inherited autosomal dominantly, there is a risk of the disorder being handed down from generation to generation.

The syndrome consists of six major features which may appear in any combination and to any degree in the affected individual. The six characteristics are:

1) Shortening of the palpebral fissures due to malpositioning of the canthic folds.

2) Heterochromic irides, which is variegated eye colour.

3) Prominent broad root of the nose.

4) Synophrys or hypertrichosis of the eyebrows.

5) White forelock

6) Varying degrees of deafness.

\section{HISTORICAL BACKGROUND}

The first recorded report of the syndrome, which was later to bear Waardenburg's name, was in 1905 when Hammerschlag described a patient with 3 of the 6 features constituting the syndrome. Further reports followed from Van der Hoeve (1916) who described twins, Mende (1926) who demonstrated the dominant inheritance of the defect, Gates (1938) who descrbed a Singalese family with blue eyes and Walsh (1947) who wrote an article concerning an affected brother and sister. Finally Waardenburg in Utrecht in the Netherlands (1948) discussed his first case, a 72-year-old man who manifested some of the symptoms. After reviewing the literature, Waardenburg examined 1050 residents of the schools for the deaf in Holland. $\mathrm{He}$ found 13 new cases with the same cluster of characteristics and subsequently wrote his paper discussing the new syndrome (Waardenburg ${ }^{1}$ ).

\section{THE PRESENT STUDY}

The Department of Human Genetics of the University of Cape Town and Groote Schuur Hospital has undertaken a number of studies in the schools for the deaf, in which the genetic nursing sisters working in this department have participated (Groenewald and Duggan ${ }^{2}$ ). Nearly 4000 children have been investigated and over 60 cases of Waardenburg's syndrome have been diagnosed. The writer was personally involved in the last study in which 14 children with the syndrome were identified.

As there are over 200 types of deafness it may be difficult to distinguish one from another. This difficulty is increased as the degree of deafness can vary greatly between cases of the syndrome.

The main feature we used to identify the children showing the syndrome was eye colour. This is an easily observed phenomenon and therefore is fairly reliable for accurate diagnosis. Some of the other pointers are prone to subjective estimations (e.g. inter-ocular distance as there are few tables giving 'normal' measurements) or may be difficult to pick up (e.g. the presence of a few white hairs representing a white forelock). Where the eye colour suggested the diagnosis, we examined the children fully for other signs of the disorder.

In the present study our figures are based on the 14 children the writer saw in the most recent survey. Percentages given therefore may not be as significant as those in larger studies, but are still of interest.

Table I shows the presence or absence of each trait. Apart from the first 3 children, who are siblings, the children are unrelated. 


\begin{tabular}{ccc}
\hline Subj. & Eyes \\
Hypertel & Colour & Hypertrichosis Forelock Deafness
\end{tabular}

\begin{tabular}{|c|c|c|c|c|c|}
\hline RH & $\bullet$ & • & & & - \\
\hline $\mathrm{GH}$ & - & - & - & vitiligo & - \\
\hline NH & - & - & • & • & $\bullet$ \\
\hline AD & - & • & & & - \\
\hline KW & & • & & & - \\
\hline EP & - & - & - & & - \\
\hline DU & • & - & - & & $\bullet$ \\
\hline RH & $\bullet$ & • & - & & - \\
\hline L B & $\bullet$ & • & • & & $\bullet$ \\
\hline MS & - & heteroch & - & & - \\
\hline MT & & - & & & - \\
\hline DP & $\bullet$ & • & & • & $\bullet$ \\
\hline HE & - & - & - & & - \\
\hline GV & - & - & & & - \\
\hline
\end{tabular}

Table I.

The features seen in the subjects of the present study.

Key. feature is present in the individual
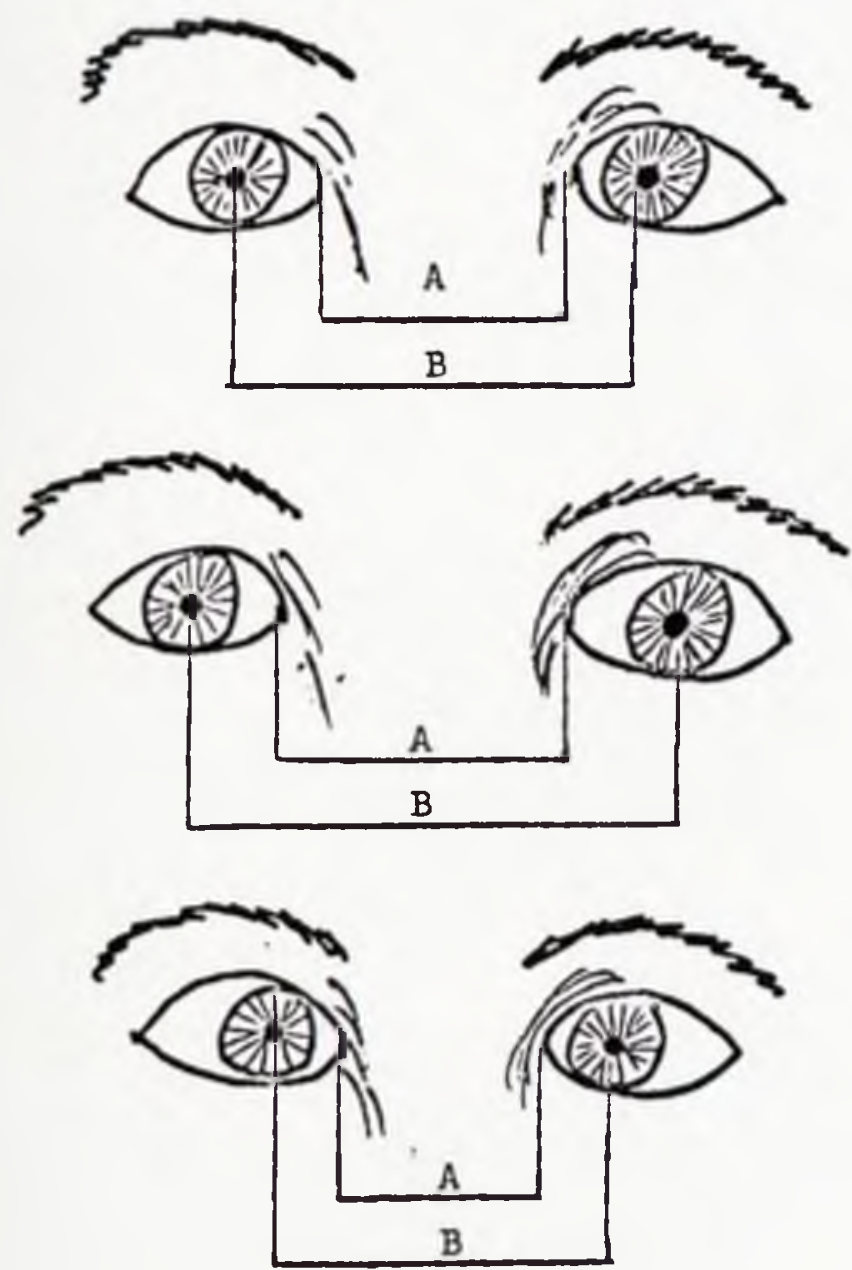

Diagrams showing the varying measurements in 3 anatomical conditions of the eye

A - inner canthic fold measurements

B - interpupillary distance
In this paper there will be a brief discussion of each symptom, a précis of the available information as well as the comparative incidence found in the literature.

\section{INCIDENCE AND OBSERVATIONS OF THE FEATURES FOUND IN THE SYNDROME}

\section{Shortening of the Palpebral Fissures}

Dystopia canthorum is the malpositioning of the canthic folds which causes the palpebral fissures (the line formed by the eyelids) to be shortened horizontally. There is a known normal range for adult Caucasians with which patients can be compared, but there is little information related to other races or to children. However, measurements can be taken to eliminate the diagnosis of hypertelorism or of convergent strabismus, both of which can produce a misleading appearance.

The apparent increased inter-ocular distance seen in Waardenburg syndrome is shown in Diagram 1. In fact Stedman's medical dictionary defines dystopia canthrum as "Waardenburg's syndrome".

$$
\begin{aligned}
& \text { Diagram } 1 \text { Dystopia Canthorum } \\
& \text { A - increased } \\
& \text { B - normal }
\end{aligned}
$$

Diagram 3 Internal Strabismus
$A-$ normal
$B-$ decreased

In hypertelorism the whole eye-orbit is displaced laterally, while in internal strabismus and Waardenburg syndrome it is normally positioned. It may therefore be of value to measure the inter-pupillary distance. The presence of epicanthic folds can be excluded by checking the positions of the inferior lachrymal punctae. In 
the event of epicanthic folds the points are normally positioned, whereas in dystopia canthorum they are displaced laterally.

Although dystopia canthorum is the most common feature seen in these patients, there are no clear-cut tables of normality. Variations which may occur could lead to conflicting reports of the incidence of this characteristic.

The percentages of the affected patients showing this sign range from $99 \%$ (Waardenburg') to about $50 \%$ (Tsafrir ${ }^{3}$ ). In the current study the writer found $79 \%$ with apparent hypertelorism. However, there may have been some ethnic bias as most of the subjects were of mixed racial origin.

\section{Heterochromia Irides}

In most people the irides are the same colour bilaterally. A notable feature in those with the syndrome under discussion is the difference in the eye colour between the left and right iris or between segments of the same iris. The heterochromia may range from both eyes being an abnormal but distinctive bright blue to only one segment of one iris showing that colour. There is little difficulty in recognising the colour of the blue once it has been seen.

It is reported that embryologically the eyes are this deep blue colour initially, and that the normal process of change to the eye colour carried by the parental gametes is interrupted (Fisch ${ }^{4}$ ). The actual structure of the iris is also undeveloped and hypoplastic.

There seems to be agreement that there is not much difference between the figures for Caucasians and Negroes showing this feature. Waardenburg ${ }^{1}$ reported $25 \%$ of his cases showing true heterochromia, whereas $81 \%$ had some hypopigmentation. Other reports vary from $50 \%$ (Pantke $e t a l^{5}$ ) to $87 \%$ (Tsafrir ${ }^{3}$ ). In the study in which the writer participated every child had heterochromic irides. However, as we had seen them in the schools for the deaf and had used eye colour as a distinguishing feature, this may be a biased figure.

The hypoplastic irides seem to have no effect on the visual acuity. There is no photophobia nor nystagmus nor any other signs associated with albinism. Nevertheless, although the structure of the fundus appears normal, there have been reports of albinoid areas in the fundus corresponding to the hypoplastic areas in the iris (Konigsmark et $a \ell^{6}$ ).

Care must be taken that the colour is not caused by other factors. These may include infection, nerve damage, cutaneous albinism and an X-linked deafness (Pantke ${ }^{5}$ ). In the writer's observations of the children in the schools for the hard of hearing, there were two sisters who each had one blue eye. As they were also deaf an erroneous "on the spot" diagnosis of Waardenburg syndrome could have been made. Both children, however, had a history of eye infections after which the colour of the eye changed.

\section{Broad Prominent Nasal Root}

It may be difficult to assess this trait, especially if inter-racial studies are done. There are few normality tables and those tabulated are only for Caucasians. One author said that this feature was only apparent due to the dystopia canthorum and the hypertrichosis of the eyebrows $\left(\mathrm{Fisch}^{4}\right)$. In fact he reported that a number of his patients suffered from depressed nasal bridges and had had sinusitis while children as a consequence. Waardenburg' thought this trait was due to hyperplasia of the frontal bones as well as hypertrichosis. This could tie up with defective development causing the white forelock and the occasions of cleft lip and palate.

The presence of this characteristic varies from a reported $78 \%$ (Waardenburg ${ }^{1}$ ) with a totally Caucasian study group, to $15 \%$ (Tsafrir ${ }^{3}$ ) with a totally Negroid group. In the writer's group there were no easily recognised cases with this sign.

From the above it can be seen that this peculiarity may not, in fact, be a distinctive component of the syndrome. It may be apparent only in the presence of other features.

\section{Hypertrichosis and Synophrys of the Eyebrows}

A fourth sign observed in the syndrome is an overgrowth of the eyebrows, especially of the medial third. This tends to cause an approximation of the eyebrows or even results in them growing together (synophrys). The original paper reported an incidence of $45 \%$ of patients showing this trait which seems to be supported by other evidence. An exception is Tsafrir ${ }^{3}$ who desribes only $17 \%$ of her subjects showing this sign. This may be due to the lack of facial hair in the Negro. In the present study $57 \%$ of the children had overgrown eyebrows.

This feature does occur in other syndromes such as the Cornelia de Lange and other rare disorders as well as in normal people. However in Waardenburg syndrome there is no increase in body hair, which facilitates differential diagnosis.

\section{White Forelock}

This trait may be present as a few white hairs in the centre of the anterior hairline to a full blaze of unpigmented hair. There may also be white hairs in the eyebrows and eyelashes. Another related sign is premature greying which presumably cannot be recognised in young children. However premature greying can run in families who do not have the Waardenburg syndrome.

An interesting observation is reported by Feingold $e t$ al who had some subjects with the forelock present at birth, but who said that it disappeared as they grew older (McKusick ${ }^{7}$ ).

In his original article Waardenburg' stated that $17 \%$ of his subjects showed some degree of greyness. Petersen $e t a l^{8}$ reported that $48 \%$ of his cases had poliosis (general greying of the hair) and $33 \%$ showed premature greying. He did not say whether these signs appeared in the same people. In the writer's sample there were two children with small white forelocks.

\section{Deafness}

The degree of deafness in the Waardenburg syndrome ranges from complete deaf-mutism to bilateral or unilateral partial loss of hearing. There seem to be conflicting reports as to the actual type of deafness involved. However, accumulated evidence points to the hearing loss being in the middle and lower ranges rather than 
in the upper ranges. The deafness is present at birth and is not progressive.

Tsafrir ${ }^{3}$ recorded $62,5 \%$ of her cases with some hearing loss as compared to Waardenburg's ${ }^{1}$ report of $20 \%$. This was in spite of the fact that Waardenburg traced his cases through the schools for the deaf. The difference may be due to the fact that he was able to trace more relatives of his subjects (in Holland) than Tsafrir was able to do in South Africa.

In this study there was not sufficient time to study all the family members who were not in the special schools. The writer therefore found that all the subjects were hard of hearing. For this reason these results for this characteristic cannot be taken as truly representative of the incidence of deafness. It does, however, point out the most serious problem that these children have to face.

Trait $\begin{array}{cc}\text { Number in } & \text { Percentages } \\ 1951 & 1978\end{array}$

\begin{tabular}{|c|c|c|}
\hline Hypertelorism & 99 & 79 \\
\hline Blue Eyes & & \\
\hline Heterochromia ) & 81 & 100 \\
\hline Nasal Root & 78 & $?$ \\
\hline Eyebrows & 45 & 57 \\
\hline White Forelock & 17 & 14 \\
\hline Deafness & 20 & 100 \\
\hline
\end{tabular}

Table II. The comparative percentages between Waardenburg's original study and the present one

\section{Other Reported Features Found With the Syndrome}

Features such as cleft lip and/or palate; high arched palate; malformed or absent uvula; patent metopic suture; mandibular prognathism and vitiligo have all been reported. The only related signs for which figures have been quoted are cleft lip and/or palate (Gorlin ${ }^{7}$ gives the figure of $3 \%$ ) and vitiligo (Tsafrir ${ }^{3}$ quotes $16,7 \%$ and Gorlin ${ }^{7}$ gives the figure as 15\%). Fisch reported seeing some of his subjects with a dappled skin. We found one child with obvious vitiligo and it is interesting that his brother had a white forelock. Vitiligo appears to be one aspect of Waardenburg's syndrome which he did not document.

\section{Differential Diagnosis}

Differential diagnoses can be wrongly made. Hypertelorism may result in the child being diagnosed as havng Down syndrome, especially where deafness causes an apparent low I.Q.

Cutaneous albinism or classical piebaldism is an autosomal dominant trait which is not related to deafness, but which does have a triangular shaped forelock from the anterior hairline sometimes involving the medial third of the eyebrows (Harris and Hirschhorn ${ }^{9}$ ).

As the defect is passed from generation to generation, different aspects of the syndrome may be observed in related individuals. Thus, due to the variable expressivity of the gene, the correct diagnosis may not be recognised.

\section{Histological and Auditory Investigations}

There has only been one recorded case of a histological investigation. Fisch ${ }^{4}$ reported the postmortem result of a young child who died following surgery for oesophageal atresia. He studied the inner ear and the brain. It was found that the organ of Corti was absent in all the coils of the cochlea. He also found that parts of the auditory nerves were poorly developed. The other findings were normal.

In 1968 Marcus found that auditory examination of 16 cases of Waardenburg syndrome showed only one of them to have a normal vestibular system (Konigsmark and Gorlin ${ }^{6}$ ).

\section{POSSIBLE EMBRYOLOGICAL BASES FOR WAARDENBURG SYNDROME}

There are several hypotheses as to the basic defect causing this syndrome. No single hypothesis is fully supported and, until further investigation is done, workers will have to weigh the pros and cons of each study.

\section{Migration of Cerebro-spinal Fluid Blebs}

Tsafrir ${ }^{3}$ feels that this is the most likely cause of the defect. She hypothesises that during embryological development a fault occurs in which blebs or blisters of C.S.F. are formed. These interfere with the normal development of the neural crest cells.

The theory that the blisters of C.S.F. cause the same developmental fault in every case seems unlikely.

\section{First Arch Syndrome}

There are a number of genetic disorders which could resemble the Waardenburg syndrome. Some of them are the Pierre-Robin syndrome, the Treacher Collins syndrome and the cleft lip and palate syndrome. All of these have some form of interference with the formattion of the features in the midline of the face. However, people with the Waardenburg defect appear to have less involvement of the midline structures and have a high proportion of deafness. This reduces the likelihood of a connection between the two syndromes.

\section{Possible Connections With Status Dysraphicus}

Status dysraphicus is the failure of the development of the midline structures, not only of the face but of any other part of the body such as syringomelia. This may tie up with the presence of the forelock, dystopia canthorum and other facial lesions, but does not explain why there is vitiligo, deafness and no other midline deformities.

\section{Developmental Fault in the Neural Crest}

Several workers have shown that the neural crest is concerned with the formation of the auditory organs and the pigmentary cells (Horstadius, Du Shane and Rawles in Fisch ${ }^{4}$ ). If there is a malformation in the embryological stage, one can hypothesise the development of faulty hearing and pigmentation. This theory is supported by work done on mice by Deal, as reported in Konigsmark and Gorlin ${ }^{6}$.

Relationships With Other Pigmentary Hearing Defects

It is a known fact that white animals are often deaf or hard of hearing. There have been a number of 
histological studies carried out on the ears of these animals and it has been suggested that the defect occurs in the first few days of intra-uterine life, at least in the case of white cats (Bosher and Hallpike in Mckusick'). There may be other instances of deafness and piebald colouring, but until researchers can find the cause and the tie-up between the two it will be difficult to trace the origin of the defect.

\section{Genetic Considerations}

Although there has been no irrefutable proof as to the embryological basis of the Waardenburg syndrome, the actual mechanism of the inheritance is easier to prove and accept.

Waardenburg himself produced large family trees showing that the syndrome had an autosomal dominant inheritance, that is, the expression of a trait in an individual who carries both the "normal" and the "abnormal" gene on his autosomes. The autosomes are chromosomes other than his sex chromosomes.
This fact has been generally accepted. Although there is a dominant form of inheritance there is very variable expressivity and penetration. This means that any of the signs in any combination and degree may appear in the affected individual. When the parent with the defect shows one aspect, such as the white forelock, the child may or may not show this feature and may easily show any of the other phenomena.

Studies on the chromosomes have not revealed any abnormalities. However, techniques are improving rapidly and future research may indeed be able to pinpoint the defective area.

The nurse should recognise the risk run by each generation of inheriting this disorder. Due to the hardships which can result from deafness, especially if untreated, medical staff at genetic clinics are available to give counselling when requested. This should make the family aware of the chance of the defect being inherited by the of fspring and thus bring to their attention the importance of having each child checked for hearing problems (Beighton ${ }^{10}$ ).

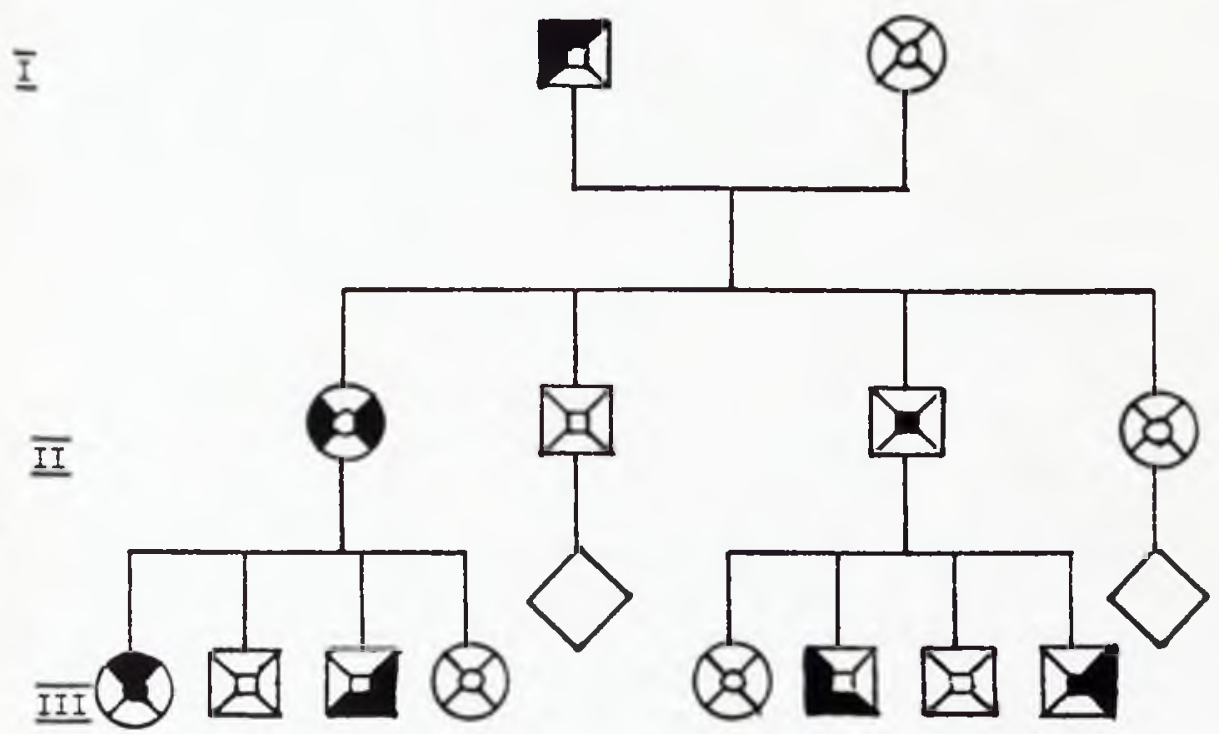

Key to Pedigree

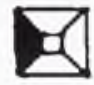

dystopia canthorum

2

hypertrichosis and prominent nasal root

区

heterochromia irides

white forelock

deafness

Pedigree to show Dominant Inheritance and Variable Expressivity in Waardenburg's Syndrome (adapted from Waardenburg' ${ }^{1}$ ). 


\section{COMMENT}

The features which constitute Waardenburg syndrome were first discussed in 1905 by Hammerschlag. However, it remained for Waardenburg in 1951 to assimilate the data and to present it as a new syndrome. There are six basic features of the syndrome which most workers accept, but the actual proportions by which each is represented vary from study to study. Apart from this there are reports of other findings which are linked or run parallel with the disorder.

There are two main problems for which help needs to be given to those manifesting the syndrome. The most important one is deafness. Assistance can be given by means of hearing aids and/or training in the schools for the deaf or hard of hearing. It must be remembered that the deafness can be profound regardless of the involvement of the parent's hearing.

Another trait which may cause problems is noticeable vitiligo or an extensive white forelock. There is little which can be done to disguise the unpigmented skin but hair dye can be used on the forelock.

Therefore, although this syndrome does not have an effect on the life-span of the individual concerned, there are difficulties for which he needs help.

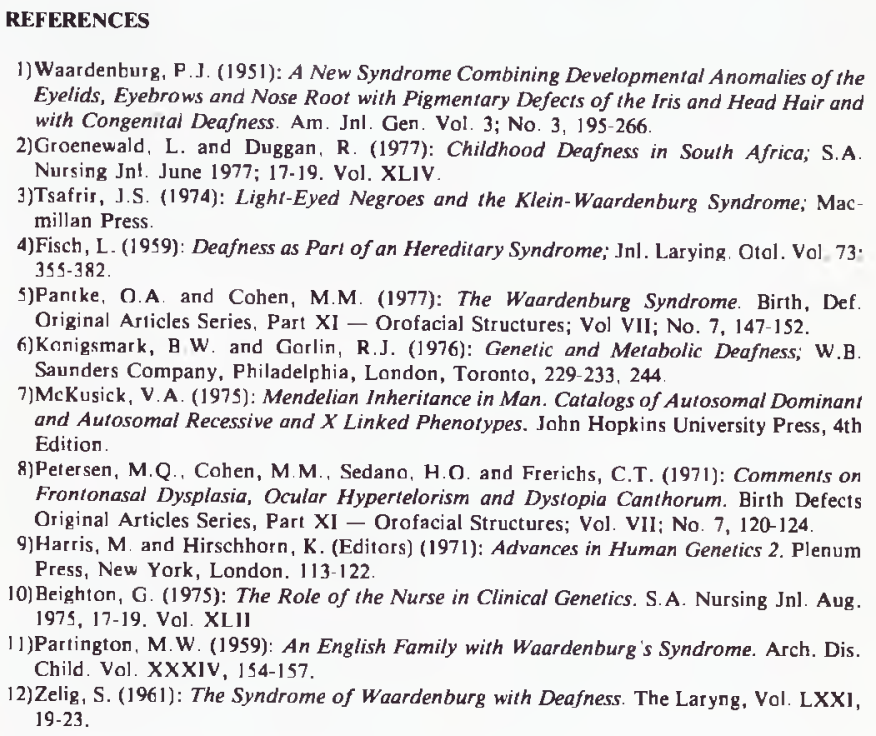

1) Waardenburg, P.J. (1951): A New Syndrome Combining Developmental Anomalies of the Eyelids, Eyebrows and Nose Root with Pigmentary Defects of the Iris and Head Hair and with Congenital Deafness. Am. Jnl. Gen. Vol. 3; No. 3, 195-266.

2)Groenewald, L. and Duggan, R. (1977): Childhood Deafness in South Africa; S.A Nursing Jnt. June 1977; 17-19. Vol. XLIV

3)Tsafrir, J.S. (1974): Light-Eyed Negroes and the Klein-Waardenburg Syndrome; Mac millan Press.

4)Fisch, L. (1959): Deafness as Part of an Hereditary Syndrome; Jnl. Larying Otol. Vol 73

5)Pantke, O.A and Cohen, M.M. (1977): The Waardenburg Syndrome. Birth, Def Original Arlicles Series, Part XI - Orofacial Structures; Vol VII; No. 7, 147-152.

6)Konigsmark, B W. and Gorlin, R.J. (1976): Genetic and Metabolic Deafness; W.B.

Saunders Company, Philadelphia, London, Toronto, 229-233, 244

7)McKusick, V.A. (1975): Mendelian Inheritance in Man. Catalogs of Autosomal Dominan and Autosomal Recessive and $X$ Linked Phenotypes. John Hopkins University Press, 4th Edition

8)Petersen, M.Q., Cohen, M.M., Sedano, H.O. and Frerichs, C.T. (1971): Comments on

Frontonasal Dysplasia, Ocular Hypertelorism and Dystopia Canthorum. Birth Defects

Original Articles Series, Part XI - Orofacial Structures; Vol. VII; No. 7, 120-124.
9)Harris, M. and Hirschhorn, K. (Editors) (1971): Advances in Humam Genetics 2. Plenum

9) Harris, M. and Hirschhorn, K. (Edit

Press, New York, London. 113-122.
10) Beighton, G. (1975): The Role of the Nurse in Clinical Genetics. S. A. Nursing Jn]. Aug. 1975, 17-19. Vol. XLII

11)Partington, M.W. (1959): An English Family with Waardenburg's Syndrome. Arch. Dis. Child Vol XXXIV, 154-157.

12)Zelig, S. (1961): The Syndrome of Waardenburg with Deafness. The Laryng, Vol. LXX1, 19-23.

\section{BOOK REVIEWS}

\section{PLANNING AMBULATORY SURGERY FACILITIES}

by R.D. Grubb and G. Ondov (C.V. Mosby Company, St. Louis, U.S.A., 1979). Price (approx): R20,50

The ambulatory surgery facilities concept is similar to the narco-clinic concept in the R.S.A.

The underlying philosophy is that the required surgical services can be completed safely within one day from admission to discharge. This is a major resource for meeting the increased demands on health services.

Aspects discussed in planning such a unit include: framework for the planning and building processes; standards to be set; budgeting; personnel aspects; ancillary services; ethics; legal aspects and public relations; equipment evaluation and use.

The chapter (Ch.10) on emotional aspects of surgery provides insight into the emotional trauma necessarily associated with surgery - however minor.

The final chapter (Ch.13) is a guide to setting up a policy and procedure manual for ambulatory surgery facilities. Aspects covered in reasonable detail include employment practices; posture and body mechanics; the principles of sterile technique, operative skin preparation; surgical trays; guidelines for assisting the patient from recovery to ambulation and nursing care plans.

\section{THE OLDER PATIENT: A TEXTBOOK OF GERIATRICS}

deur R. E. Irvine, M. K. Bagnall en B. J. Smith, (Hodder \& Stoughton Ltd., Kent, Surrey 1978)

Die slapbanduitgawe van hierdie outeurs wat handel oor die bejaarde pasiënt is verdeel in twee afdelings:

\section{AFDELING I}

Hierdie afdeling handel oor die ouer persoon en sy versorgingsbehoeftes. Fasette wat hierin behandel word is onder andere:

* die effekte van veroudering

* die bejaarde en die gemeenskap

* die bejaarde en sy gesin

* die bejaarde in die geriatriese eenheid

Spesifieke behoeftes met betrekking tot toiletgewoontes, voeding, sintuiglike deteriorasie, rehabilitasie en terminale versorging word ook bespreek.

\section{AFDELING II}

In hierdie afdeling word aandag gegee aan die siektetoestande waarmee die bejaarde probleme ondervind, byvoorbeeld ten opsigte van sirkulatoriese toestande, siektes van die senuweestelsel, organiese geestessiektetoestande, infektiewe toestande ensovoorts.

Dit is ' $n$ baie basiese en praktiese handleiding wat baie waardevol kan wees in byvoorbeeld tehuise vir bejaardes; geriatriese afdelings; ensovoorts.

Die hoofstuk oor die terminale versorging verdien spesiale vermelding aangesien verpleegpersoneel dikwels self onsekerheid ten opsigte van hierdie aspek ondervind.

S.P. HUMAN 